\title{
Investigation of Schiff Bases Containing Acryloyl Moiety as Ionophore in Potentiometric Ion-Selective Sensors
}

\author{
Osman ÇUBUK $^{1^{*}}$, Gülüzar KIRANLIOĞLU ${ }^{2}$, Fatih ÇOLDUR $^{1}{ }^{\mathbb{D}}$, Sevil \\ ÖZKINALI ${ }^{3}$ \\ 1 * Erzincan Binali Yıldırım Üniversitesi, Fen-Edebiyat Fakültesi, Kimya Bölümü \\ 2 Erzincan Binali Yıldırım Üniversitesi, Fen Bilimleri Enstitüsü, Kimya Anabilim \\ Dalı \\ ${ }^{3}$ Hitit Üniversitesi, Fen-Edebiyat Fakültesi, Kimya Bölümü \\ Geliş / Received: 11/06/2021, Kabul / Accepted: 30/06/2021
}

\begin{abstract}
In this study, all-solid-state chromium (III) selective potentiometric poly(vinylchloride) (PVC) membrane sensors were constructed by using the newly synthesized ionophores called (E)-4-((4-nitrophenylimino) methyl) phenyl acrylate (A1), (E)-4-((4-chlorophenylimino) methyl) phenyl acrylate (A2) and (E)-4-(4hydroxybenzylideneimino) benzoic acid acrylate (A3). The most suitable membrane composition, which has the best potentiometric characteristics, was examined by using membrane cocktail coated electrodes containing the ionophores, o-nitrophenyloctyl ether (o-NPOE), bis(2-ethylhexyl) sebacate (DOS), dibutyl phthalate (DBP), dioctyl phthalate (DOP) and PVC. In addition, the effect of potassium tetrakis(4-chlorophenyl) borate (KTpClPB) and sodium tetraphenylborate (NaTPB) as ionic additives was investigated to determine optimum membrane composition. The optimum membrane composition was determined as $1.0 \%$ (w/w) A2, $67.0 \%$ (w/w) o-NPOE, and $32.0 \%(\mathrm{w} / \mathrm{w})$ PVC. On the condition of $\mathrm{pH} 3.50$ the prepared electrode exhibited a linear response over the concentration range of $1.3 \times 10-7-1.0 \times 10-1 \mathrm{M}$ chromium (III) ion solutions (R2=0.9938) with a sensitivity of $27.1 \pm 0.8 \mathrm{mV} /$ decade, detection limit of $6.3 \times 10-8 \mathrm{M}$ and short response time of $\leq 10 \mathrm{~s}$. The influences of some widely used cation species over electrode responses were studied. In order to investigate whether the proposed electrode could be used analytically, potentiometric determination of chromium (III) ion was carried out in real samples. The results were statistically compared with the Inductively Coupled PlasmaMass Spectrometry (ICP-MS) method.
\end{abstract}

Keywords: Ion-selective electrode, Chromium (III) determination, Potentiometric sensor, Schiff bases Ionophores.

\section{Akriloil Grup İçeren Schiff Bazlarının Potansiyometrik İyon-Seçici Sensörlerde İyonofor Olarak Kullanımının Araştırılması}

$\ddot{\mathbf{O z}}$

Bu çalışmada, yeni sentezlenen iyonoforlar kullanılarak tümüyle katı-hal krom (III)-seçici potansiyometrik polivinil klorür (PVC) membran sensör geliştirildi. Bu amaçla yeni sentezlenen akriloil grup içeren (E)-4-(4Nitro fenilimino) metil fenil akrilat (A1), (E)-4-(4-kloro fenilimino) metil fenil akrilat (A2) ve (E)-4-(4hidroksibenzil dimino) benzoik asit akrilat (A3) schiff bazları iyonofor olarak kullanıld1. En uygun potansiyometrik özelliklere sahip membran bileşimi farklı oranlarda iyonoforlar (A1, A2 ve A3), plastikleştiriciler (o-nitrofeniloktil eter (o-NPOE)), bis (2-etilheksil) sebekat (DOS), dibutil ftalat (DBP), dioktil ftalat (DOP) ve PVC kullanılarak belirlendi. Ayrıca, optimum membran kompozisyonunu belirlemek için iyonik katkı maddesi olarak potasyum tetrakis(4-klorofenil) borat (KTpClPB) ve sodyum tetrafenilboratın (NaTPB) etkisi araştırıldı. Geliştirilen krom (III)-seçici sensör için \% 1,0 A2 bileşiği, \% 67,0 (a/a) o-NPOE ve \% 32,0 (a/a) PVC oranları en uygun membran bileşimi olarak belirlendi. Geliştirilen krom

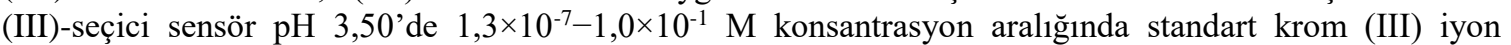
çözeltisine karşı doğrusal cevap sergiledi $\left(\mathrm{R}^{2}=0,9938\right)$. Sensör ile doğrusal çalışma aralığındaki her onkat'lık

\footnotetext{
*Corresponding Author: kimyager19@gmail.com
} 
Investigation of Schiff Bases Containing Acryloyl Moiety as Ionophore in Potentiometric Ion-Selective Sensors standart krom (III) konsantrasyon değişiminin ortalaması 27,1 $\pm 0,8 \mathrm{mV}$ 'luk eğim değeri, tekrarlanabilir potansiyeller elde edildi. Geliştirilen tümüyle kat1-hal krom (III)-seçici potansiyometrik PVC membran sensörün tayin limiti $6,3 \times 10^{-8} \mathrm{M}$ ve cevap süresi $\leq 10 \mathrm{~s}$ olarak belirlendi. Yaygın bazı katyon türlerinin geliştirilen sensör üzerindeki girişim etkileri incelendi. Önerilen sensörün analitik olarak kullanılıp kullanılamayacağını araştırmak için, gerçek numunelerde krom (III) iyonunun potansiyometrik tayini gerçekleştirildi. Elde edilen sonuçlar İndüktif Eşleşmiş Plazma-Kütle Spektrometrisi (ICP-MS) metodu ile elde edilen verilerle istatiksel olarak karşılaştırıldı.

AnahtarKelimeler: İyon-seçici elektrot, Krom (III) tayini, Potansiyometrik sensör, Schiff baz iyonoforlar

\section{Introduction}

Chromium has been intensively finds applications in pigment, stainless steel and electroplating industries and releases to environment with these activities (Wilson 2019; Hamilton et al., 2018). Chromium is one of the significantly important heavy metals high level of which causes detrimental effects on the environment and living organisms.

The metal ions present in living organisms can be essential or toxic depending on their concentration levels. Cr (III) ion is an essential nutrient that helps well functioning of human physiology and indispensable for normal fat and carbohydrate metabolism (McIver et al., 2015). However, high level of $\mathrm{Cr}$ (III) can be carcinogenic and causes digestive problems and damages of kidney or liver (Altunay et al., 2018; Kimbrough et al., 1999). According to the World Health Organization (WHO) and US Environmental Protection Agency (EPA), the allowable upper concentration level of $\mathrm{Cr}$ (III) in drinking water are $0.05 \mathrm{mgL}^{-1}$ (Khound et al., 2019). In adults, the appropriate tolarable dietary intake for chromium is 50-200 g per day (National Research Council 1989). Therefore, it is crucially important to determine and monitor chromium level in industry and environment as well. Up to now, various analytical techniques have been reported for the Cr (III) determination such as ion chromatography (Michalski 2005), high-performance liquid chromatography (HPLC) (Kaur \& Malik 2009), spectrophotometry (Kumar \& Muthuselvi 2006; Zhao \& Han 1994), atomic absorption spectroscopy (Sun \& Liang 2008; Divrikli et al., 2008), fluorimetry (Elavarasi et al., 2014). But, the majority of these techniques have some limitations in terms of the properties such as needs of time-consuming, tedious and complex pretreatment processes sophisticated instruments, expert operators and expensive consumables. Therefore the development of novel alternative methods removing the above mentioned disadvantages is still a significant task for the researchers working on analytical chemistry.

Among various electrochemical methods that can be used to determine an analyte, the potentiometric method is one of the most suitable and widespreadly applied one. The reasons why potentiometric ion-selective electrodes have such a widespread application area is undoubtedly due to some of their advantages. Some of these advantages can be expressed as follows: easy preparation, low- cost, not requiring sophisticated equipments and expert operators, enabling fast, sensitive, selective and on-site determinations, ease of miniaturization, nondestructive for measurement media, not requiring tedious and time-consuming pre-processes.

In the present study, we have constructed all-solid-state chromium (III) selective potentiometric poly(vinylchloride) (PVC) membrane sensors based on some Schiff bases ionophores called (E)4-((4-nitrophenylimino) methyl) phenyl acrylate (A1), (E)-4-((4-chlorophenylimino) methyl) phenyl acrylate (A2) and (E)-4-(4-hydroxybenzylideneimino) benzoic acid acrylate (A3). The optimum membrane composition was investigated by using different ratios of ionophores and other membrane components. The applicability of the electrode for the determination of chromium (III) in real samples was also investigated. 


\section{Material and Methods}

\subsection{Reagents and Solutions}

Three different shiff bases, called (E)-4-((4-nitrophenylimino) methyl) phenyl acrylate (A1), (E)4-((4-chlorophenylimino) methyl) phenyl acrylate (A2) and (E)-4-(4-hydroxybenzylideneimino) benzoic acid acrylate (A3), which were used in the construction of the potentiometric sensors as ionophores were the chemicals synthesized and characterized in the previous study (S1lku et al., 2016). Tetrahydrofuran (THF), high molecular weight polyvinylchloride (PVC), onitrophenyloctylether (o-NPOE), dioctyl sebacate (DOS), dioctyl phthalate (DOP), dibutylphthalate (DBP), potassium tetrakis(4-chlorophenyl) borate (KTpClPB), graphite and sodium tetraphenylborate (NaTPB) was obtained from Sigma-Aldrich (Germany). Epoxy TP3100 (Denlaks, Turkey) and hardener Desmodur RFE (Bayer, Germany) were used to prepare solidcontacts. All solutions used in analytical procedures were prepared by using 18.3 $\mathrm{M} \Omega$ deionized water. The standard solutions used in the measurements were prepared from analytical grade nitrate salts of cations (Sigma-Aldrich, Germany). Solutions of each species at a concentration of $0.1 \mathrm{M}$ were prepared with deionized water as stock. Then, solutions at the required concentrations of each species were prepared from their stock solutions by gradual dilution with appropriate amounts of deionized water.

\subsection{Apparatus}

A laboratory-made computer-controlled potentiometric measurement system was used for the potentiometric measurements. Saturated $\mathrm{Ag} / \mathrm{AgCl}$ reference electrode (Gamry, USA) was operated as the reference electrode in the system. Orion Star A215 (Thermo Fisher Scientific, USA) $\mathrm{pH} /$ Conductivity measuring device was employed for $\mathrm{pH}$ adjustment of the buffer solutions. Chromium (III) analysis in real samples was performed with an Agilent 7700x Inductively Coupled Plasma-Mass Spectrometer (Agilent 7700x series ICP-MS, USA).

\subsection{Constructions of the electrodes}

In the constructions of the all-solid-state chromium (III)-selective PVC-membrane potentiometric sensors, first of all, the preparation of conductive solid contacts were performed. For this, copper wires with a diameter of 1-2 mm and a length of 10-15 cm were cut and their one open end to be used as transducers were smoothed with a sandpaper. These smoothed bare copper surfaces were then entirely coated with the conductive solid contact providing more compatable structure to attach the ion-selective membrane cocktail. The solid contact mixture consisted of $50.0 \%(\mathrm{w} / \mathrm{w})$ graphite, $35.0 \%(\mathrm{w} / \mathrm{w})$ epoxy and $15.0 \%(\mathrm{w} / \mathrm{w})$ hardener in the appropriate amount of THF. The copper wires were dipped into this mixture several times until an appropriate thickness was obtained. These coated solid contacts were dried in an oven overnight at $45-50{ }^{\circ} \mathrm{C}$ (Isildak et al., 2004).

For the preparation of the membrane cocktails, appropriate amounts of ionophore, o-NPOE, PVC and $\mathrm{KTpCIPB}$ at various ratios were weighted and dissolved in sufficient purified THF. Then, the formerly prepared conductive solid contacts were coated with the membrane cocktail by dipping into it several times. The resultant coated membrane electrodes were left to dry overnight and conditioned by immersing $5 \times 10^{-2} \mathrm{M} \mathrm{Cr}$ (III) solution for 2 days before the first use. In the following uses, the electrodes were conditioned by immersing the same solution but the conditioning period this time was 2 hours. The electrodes were kept in ambient conditions when 
Investigation of Schiff Bases Containing Acryloyl Moiety as Ionophore in Potentiometric Ion-Selective Sensors not in use.

\section{Result and discussion}

It is well known that the potentiometric performance characteristics of an electrode is depended on the composition of the selective layer. Therefore, to obtain the electrode composition performing the best potentiometric performance, the effects of the types and percentages of the membrane components were investigated. Initially, the effects of the studied ionophore types were studied. For that purpose, electrode membrane compositions containing the same components (ionophore, PVC, plasticizer and ionic additive) at the same ratio, just only ionophore type is different, were prepared. The potentiometric performance characteristics including slope, linear range and linearity degree of the calibration plots were compared to each other (Table 1).

Table 1. Potentiometric performance characteristics of sensors prepared with newly synthesized A1, A2 and A3 compounds.

For the ion with the best potentiometric performance;

\begin{tabular}{crcc}
\cline { 2 - 4 } Ionophores & $\begin{array}{c}\text { Slope, } \\
\text { mV/decade }\end{array}$ & Linear range, $\mathbf{M}$ & \multicolumn{1}{c}{$\mathbf{R}^{2}$} \\
\hline A1 & $26.1 \pm 0.3$ & $8.0 \times 10^{-3}-1.0 \times 10^{-5}$ & 0.9735 \\
A2 & $27.1 \pm 0.8$ & $1.0 \times 10^{-1}-1.3 \times 10^{-7}$ & 0.9938 \\
A3 & $16.3 \pm 0.4$ & $5.0 \times 10^{-2}-3.0 \times 10^{-5}$ & 0.5571 \\
\hline
\end{tabular}

As seen, ionophore A2 has the best potentiometric performance characteristic regarding to slope, linear range and linearity degree compared to ionophore A1 and A3. Furthermore, various membrane compositions containing A2 ionophore, plasticizer (o-NPOE, DBP, DOP or DOS), $\mathrm{PVC}$ and in some cases, ionic additive (KTpCIPB or NaTPB) were prepared and tested. When the potentiometric measurement results obtained from the membrane optimization studies were evaluated comparatively, it was determined that the electrode membrane composition, which exhibited the best potentiometric performance properties, was $1.0 \%(\mathrm{w} / \mathrm{w})$ ionophore $\mathrm{A} 2,67.0 \%$

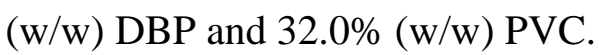

The potentiometric performance characteristics of the electrode, which was prepared according to the optimum membrane composition, were investigated in more detail. For that purpose, the linear working range of the electrode was determined by using the potentiometric measurements taken in the standard chromium (III) solutions prepared in the concentration range of $1.0 \times 10^{-1}-1.0 \times 10^{-7}$ M. The measurements taken in standard solutions are illustrated in Figure 1 and the corresponding calibration curve was shown in Figure 2. The electrode exhibited a linear response to $\mathrm{Cr}$ (III) ions in the concentration range of $1.0 \times 10^{-1}-1.3 \times 10^{-7} \mathrm{M}\left(\mathrm{R}^{2}=0.9938\right)$ with a slope of $27.1 \pm 0.8$ $\mathrm{mV} /$ decade. The lower limits of detection of the electrode was also calculated as $1.3 \times 10^{-7} \mathrm{M}$ from the intersection of the two extrapolated segments of the calibration curve according to the IUPAC recommendations (Buck \& Lindner 1994). 


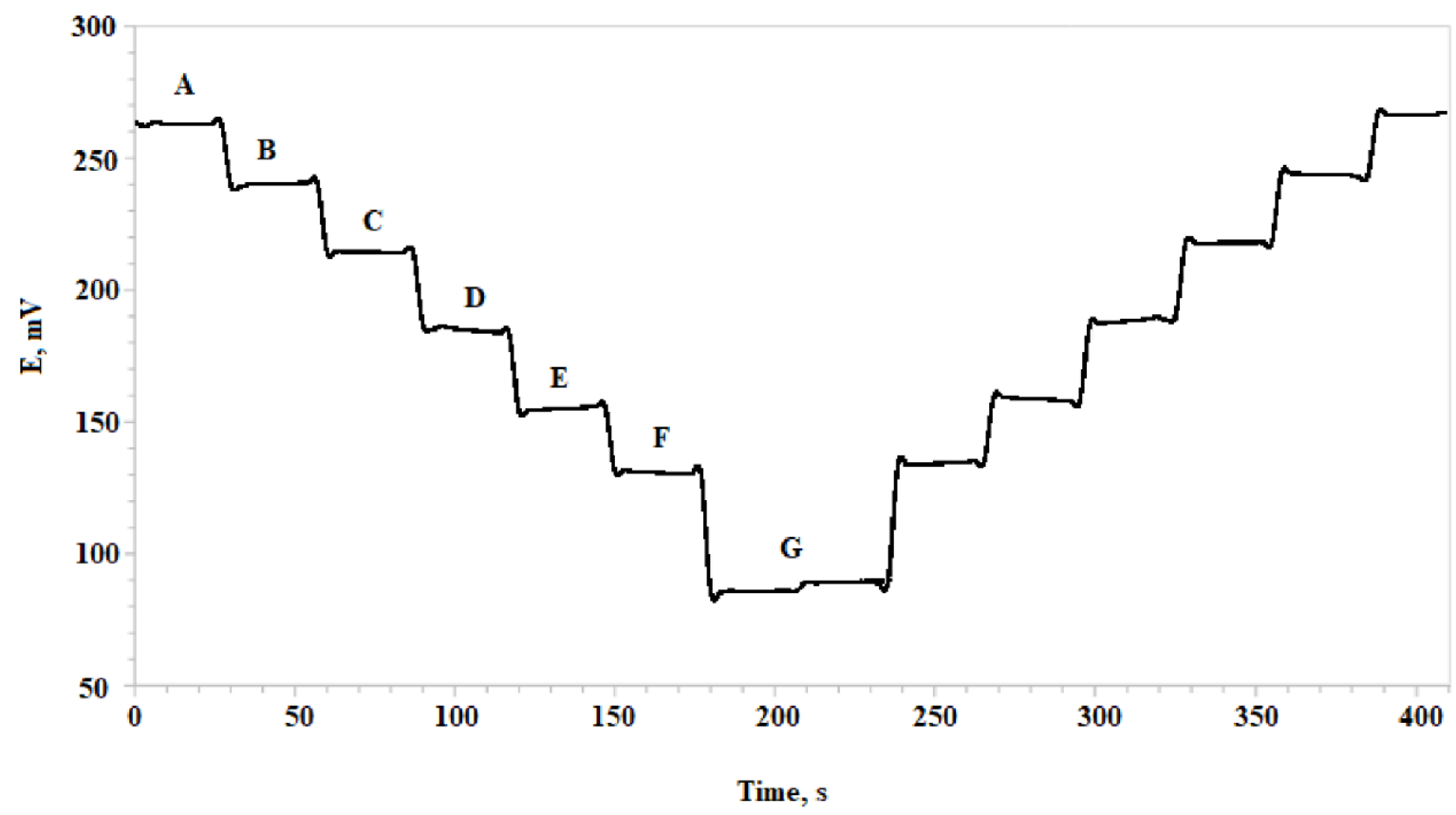

Fig 1. The potentiometric responses of the all-solid state $\mathrm{Cr}$ (III)-selective electrode to standard $\mathrm{Cr}$ (III) solutions at various concentrations. A) $1.0 \times 10^{-1} \mathrm{M}$; B) $1.0 \times 10^{-2} \mathrm{M}$; C) $1.0 \times 10^{-3} \mathrm{M}$; D) $1.0 \times 10^{-4} \mathrm{M}$; E); $1.0 \times 10^{-5} \mathrm{M}$; F) $1.0 \times 10^{-6} \mathrm{M}$; G) $1.0 \times 10^{-7} \mathrm{M}$.

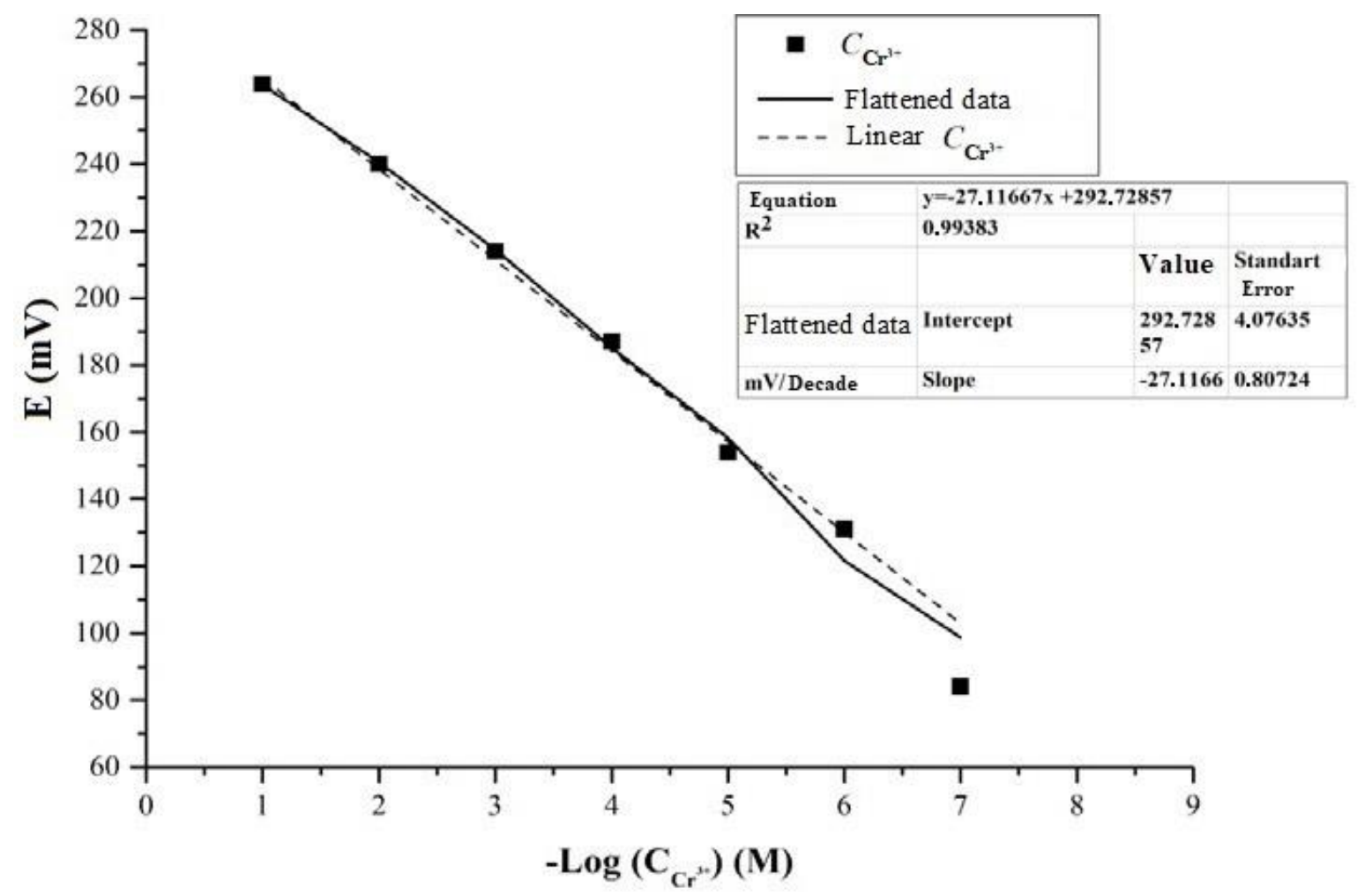

Fig. 2. The calibration curve of the all-solid state $\mathrm{Cr}$ (III)-selective electrode. 
For the determination of the response time (t95) of the all-solid-state chromium (III)-selective potentiometric PVC membrane sensor, the electrode was immersed into each of the calibration solutions respectively from low to high and from high to low concentrations. The elapsed times were recorded when the output potential of the sensor became stable in the solutions which were stirred at a constant speed ( $\left.t_{95}\right)$ (Buck \& Lindner 1994). The mean time for the potentials to reach the stable value was determined as the response time of the sensor. Figure 3. illustrates the potentiometric response of the all solid-state chromium (III)-selective electrode when the Cr (III) concentration was altered from $1.0 \times 10^{-4}$ to $1.0 \times 10^{-3} \mathrm{M}$. It is seen that the proposed all-solid-state chromium (III)-selective sensor reaches a stable potential value very quickly. This result shows that the developed all-solid-state chromium (III)-selective sensor has a fast response (about 10 s).

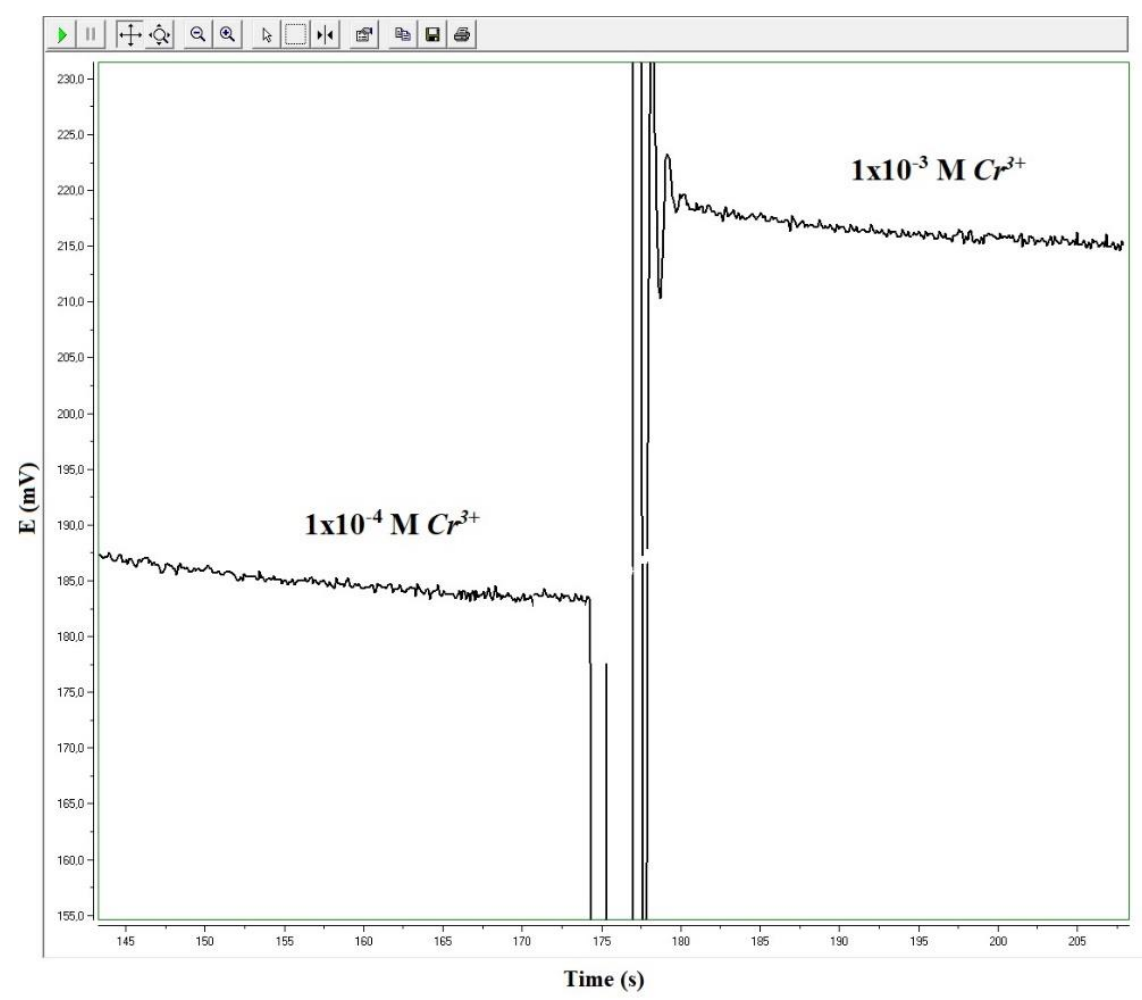

Fig. 3. The response time of the all-solid state $\mathrm{Cr}(\mathrm{III})$-selective electrode.

One of the most significant performance characteristics of an ISEs is its selectivity. An ionselective electrode can experience interferences by responding to the presence of other ions. The selectivity coefficient is a numerical indicator of how well the selective membrane can discriminate the main ion against the interfering ion. The potentiometric selectivity coefficients of the developed all-solid-state chromium (III)-selective PVC membrane sensor for chromium (III) ions against some common cationic species were calculated by using the Matched Potential Method (Gadzekpo et al., 1984) and the related selectivity coefficients for these studied cations were summarized in Table 2. As can be seen from the interpretation of the selectivity coefficients, the electrode exhibits a sufficiently selective potentiometric response to chromium(III) ions. 
Table 2. Potentiometric selectivity coefficients of all-solid-state chromium (III)-selective PVC membrane sensor for some common cationic species

\begin{tabular}{cccc}
\hline Cationic species & $\operatorname{LogK}_{\mathrm{Cr}^{3+}, X^{n+}}$ & Cationic species & $\mathrm{LogK}_{\mathrm{Cr}^{3+}, X^{n+}}$ \\
\hline $\mathrm{Na}^{+}$ & -2.91 & $\mathrm{~Pb}^{2+}$ & -1.49 \\
$\mathrm{~K}^{+}$ & -0.85 & $\mathrm{Ni}^{2+}$ & -1.78 \\
$\mathrm{Mg}^{2+}$ & -2.79 & $\mathrm{NH}^{+}$ & -2.49 \\
$\mathrm{Co}^{2+}$ & -2.79 & $\mathrm{Ca}^{2+}$ & -2.79 \\
$\mathrm{Mn}^{2+}$ & -2.59 & $\mathrm{Cu}^{2+}$ & -1.13 \\
$\mathrm{Zn}^{2+}$ & -2.40 & $\mathrm{Al}^{3+}$ & -0.85 \\
$\mathrm{Ba}^{2+}$ & -2.79 & - & - \\
\hline
\end{tabular}

To demonstrate the repeatability of the proposed chromium (III)-selective potentiometric sensor, consecutive measurements were taken in the solutions of $1.0 \times 10^{-3}, 1.0 \times 10^{-4}$ and $1.0 \times 10^{-5} \mathrm{M}$ chromium (III).

The obtained real-time potentiometric responses and their repeatabilities in these solutions are indicated in Fig. 4.

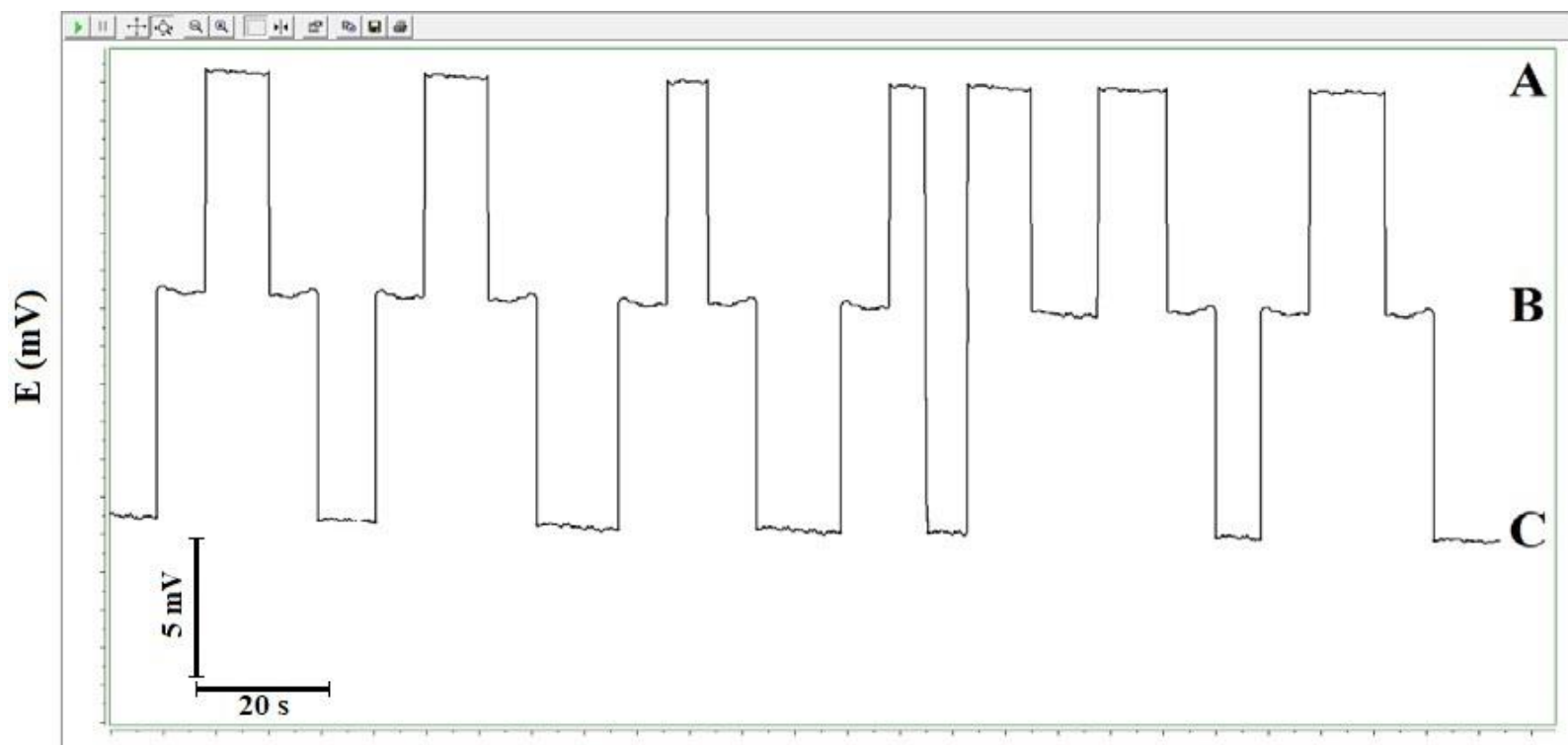

Time (s)

Fig. 4. The repeatability of the proposed all-solid-state chromium (III)-selective PVC membrane sensor A) $1.0 \times 10^{-3} \mathrm{M} \mathrm{Cr}$ (III) B) $1.0 \times 10^{-4} \mathrm{M} \mathrm{Cr}$ (III) C) $1.0 \times 10^{-5} \mathrm{M} \mathrm{Cr}$ (III).

Another important potentiometric parameter of an ion-selective electrode is $\mathrm{pH}$ working range. It is desired that the response of the electrode should remain unaffected by the $\mathrm{pH}$ of the medium over a wide $\mathrm{pH}$ range. Therefore, in order to determine the $\mathrm{pH}$ working range of the proposed electrode, potentiometric measurements were taken in a series of solutions containing $1.0 \times 10^{-3}$ and 
Investigation of Schiff Bases Containing Acryloyl Moiety as Ionophore in Potentiometric Ion-Selective Sensors $1.0 \times 10^{-4} \mathrm{M}$ chrome (III) ions at different $\mathrm{pHs}$. The variation of the electrode potential depending on the $\mathrm{pH}$ of the solutions (for $1.0 \times 10^{-3}$ and $1.0 \times 10^{-4} \mathrm{M} \mathrm{Cr}$ (III) concentrations) is seen in Figure 5. As can be seen from the graph, the potentiometric response of the developed sensor in the $\mathrm{pH}$ range of 3.50-5.00 is not affected much by the $\mathrm{pH}$ change. However, at low $\mathrm{pH}$ values $(<3.50)$ and similarly, at high $\mathrm{pH}$ values $(>5.00)$, it is seen that there are slight changes in potential values, an increase and a decrease, respectively. The potential increases at $\mathrm{pH}<3.50$ may probably due to the increase in the concentration of $\mathrm{H}_{3} \mathrm{O}^{+}$ions in the environment with the addition of $\mathrm{HCl}$ and the response of the sensor to the $\mathrm{H}_{3} \mathrm{O}^{+}$ion as well as chrome (III). The reason for the potential decrease at high pHs can be explained by the interaction of chromium (III) ions with $\mathrm{OH}$ - ions to form chromium (III) hydroxyl precipitates.

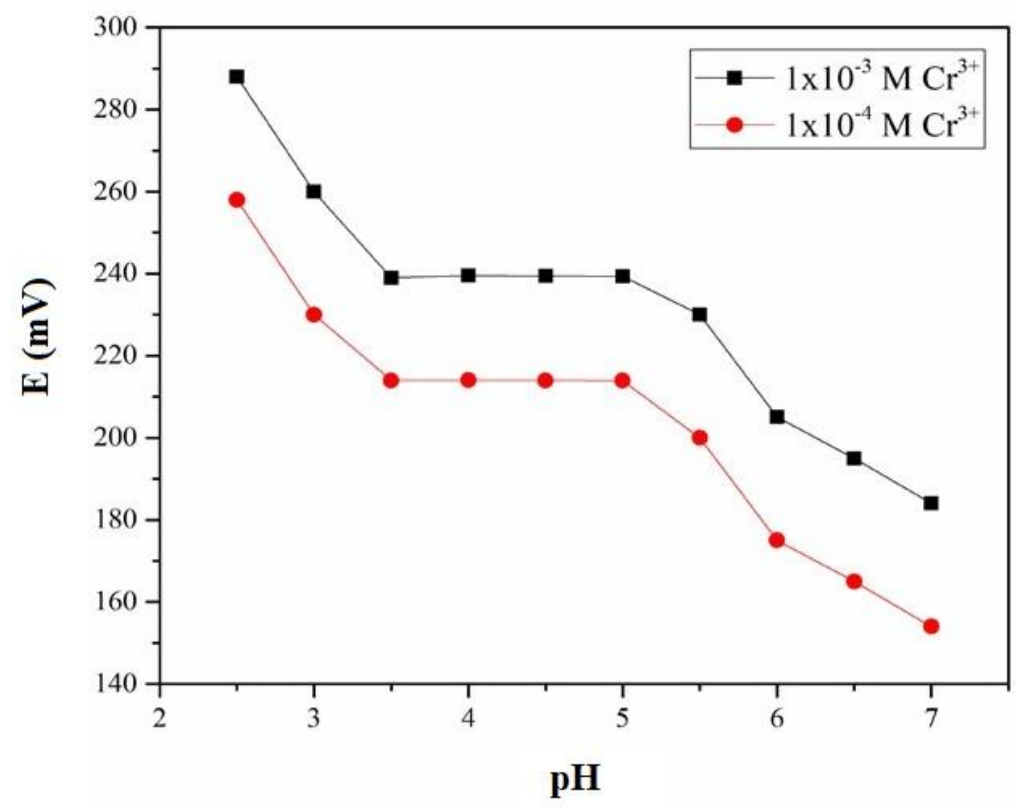

Fig. 5. The effect of $\mathrm{pH}$ on the potentiometric response of the proposed all-solid-state chromium (III)-selective PVC membrane sensor.

In order to determine the life-time of the developed all-solid-state chromium (III)-selective PVC membrane sensor, measurements in the linear range of the sensor were taken on different days and calibration lines were established. In order to monitor the time-dependent change in the slopes of the calibration lines, the obtained slope values against time were plotted (Fig. 6).

When the graph given in Figure 6. is examined, it is seen that the slope values did not change significantly during the 2 months period, but at the end of the two-months period, the initial slope value of $27.1 \mathrm{mV} /$ decade decreased to $18.5 \mathrm{mV} /$ decade. Considering the life-time of commercial sensors is the time that elapsed for its calibration slope to decrease to $70 \%$ of the initial slope value, it can be said that the life-time of the developed sensor is approximately 2 months. 


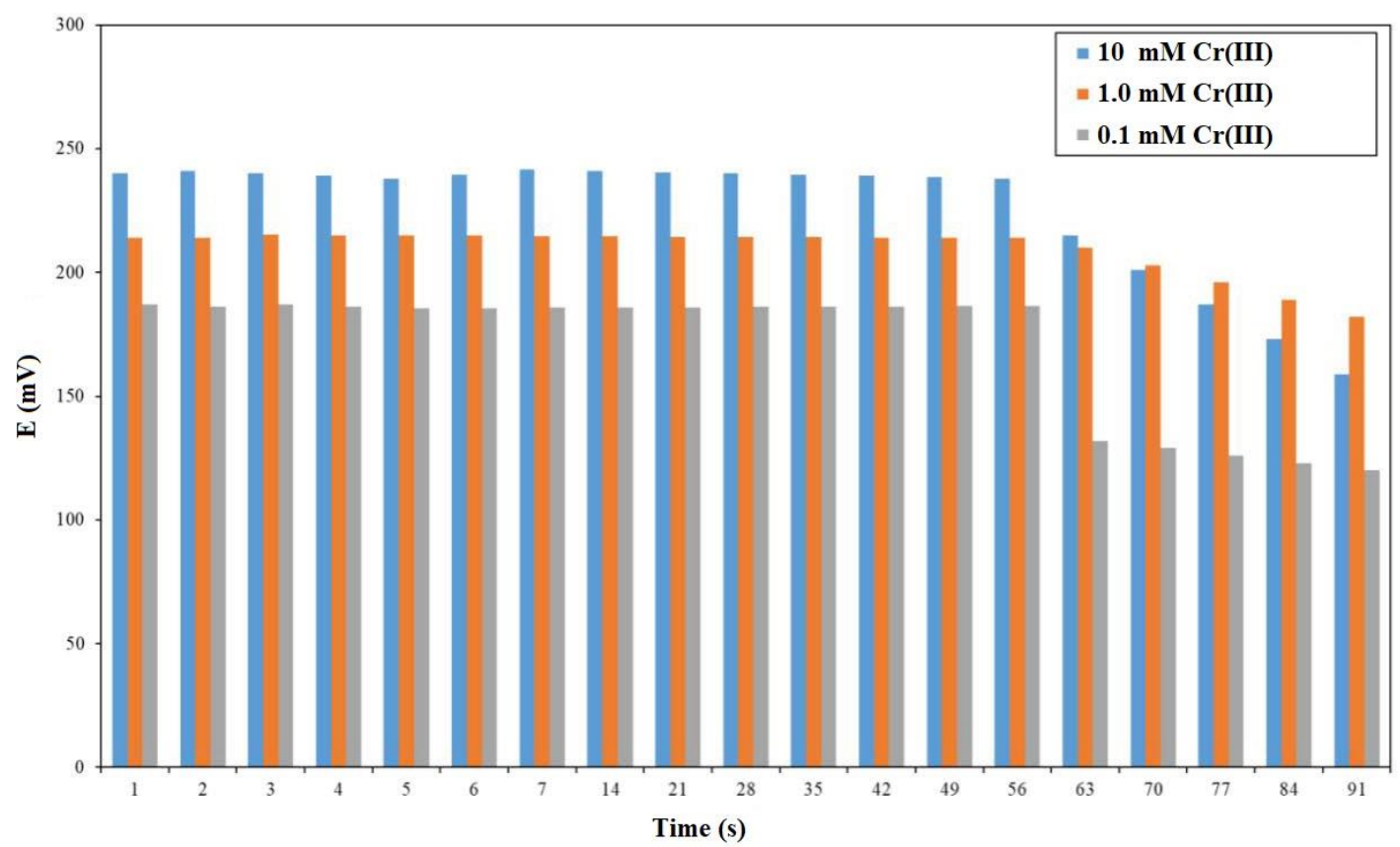

Fig. 6. The change in the slope of all-solid-state chromium (III)-selective PVC membrane sensor depending on time

In order to demonstrate the electroanalytical applicability of the developed all-solid-state chromium (III)-selective potentiometric PVC membrane sensor, chromium (III) contents of coffee, turmeric, green tea and drinking water samples were determined by the proposed sensor. In addition, the potentiometric results were compared with the results Inductively Coupled Plasma-Mass Spectrometry (ICP-MS) results. For this purpose, $1 \mathrm{~g}$ of coffee, turmeric and green tea samples were weighed and dissolved by heating in a mixture of $\mathrm{HNO}_{3}$ and $\mathrm{HCl}(5: 1)$ acid. Then, the measurements were taken by diluting the $10 \mathrm{~mL}$ acid mixture to $50 \mathrm{~mL}$ with deionized water by following the necessary procedures. The $\mathrm{pH}$ values of all the samples were adjusted to 4.00 before the analysis (Pettine et al., 2002).

The results obtained by both the potentiometric method and the Inductively Coupled PlasmaMass Spectrometer (ICP-MS) method are given in Table 3. In Table 3, it is seen that the average chromium (III) amounts obtained by both methods are quite close to each other and the developed all--solid-state chromium (III)-selective potentiometric PVC membrane sensor can be successfully applied to real samples.

Finally, some of the potentiometric performance parameters of the currently developed $\mathrm{Cr}$ (III)selective sensor were compared with those of the some $\mathrm{Cr}$ (III)-selective potentiometric sensors formerly studied and available in the literature (Table 4.). As can be seen, it can be stated that the performance characteristics of the presently developed sensor in this study are at a competitive level with those in the literature, and even some performance features are superior than most. 
Table 3. Chromium (III) amounts obtained by ICP-MS and the developed all-solidstate chromium (III)-selective PVC membrane sensor

\begin{tabular}{ccc}
\hline Sample & $\begin{array}{c}\text { ICP-MS, } \\
\mathbf{C r}^{3+}, \mathbf{p p b}\end{array}$ & $\begin{array}{c}\text { Developed all-solid-state chromium (III)-selective PVC } \\
\text { membrane sensor, } \mathbf{C r}^{3+}, \mathbf{p p b}\end{array}$ \\
\hline Coffee & $-*$ & $-*$ \\
Turmeric & $8.64 \pm 0.04$ & $8.95 \pm 0.03$ \\
Green tea & $-*$ & $-*$ \\
Drinking water & $9.02 \pm 0.02$ & $8.49 \pm 0.05$ \\
\hline
\end{tabular}

* Not observed; $N=3$

Table 4. Comparison of chromium (III) selective sensors in the literatüre

\begin{tabular}{|c|c|c|c|c|c|c|}
\hline Ionophore & $\begin{array}{l}\text { Slope } \\
(\mathrm{mV})\end{array}$ & $\begin{array}{c}\text { Linear Range } \\
\text { (M) }\end{array}$ & $\begin{array}{l}\text { Limit of } \\
\text { Detection } \\
(\mathrm{M}) \\
\end{array}$ & $\begin{array}{l}\text { Response } \\
\text { Time }\end{array}$ & $\begin{array}{c}\text { pH } \\
\text { Range }\end{array}$ & Reference \\
\hline $\begin{array}{l}\text { 4-amino-3-hydrazino-6- } \\
\text { methyl-1,2,4-triazin-5-one } \\
\text { (AHMTO) }\end{array}$ & 19.70 & $1.0 \times 10^{-1}-1.0 \times 10^{-6}$ & $5.8 \times 10^{-7}$ & $<10$ & $2.70-6.60$ & Zamani et al 2006 \\
\hline Glyoxal bis(2-hydroxyanil) & 19.89 & $1.0 \times 10^{-2}-3.0 \times 10^{-6}$ & $6.3 \times 10^{-7}$ & $<20$ & $2.70-6.50$ & Gholivand et al 2003 \\
\hline $\begin{array}{l}\text { Aurin tricarboxylic acid } \\
\text { modified silica }\end{array}$ & 19.00 & $1.0 \times 10^{-1}-7.0 \times 10^{-6}$ & - & 10 & $3.50-6.50$ & $\begin{array}{l}\text { Sharma and Goel } \\
2005\end{array}$ \\
\hline 4-dimethylaminoazobenzene & 19.50 & $1.0 \times 10^{-2}-1.66 \times 10^{-6}$ & $8.0 \times 10^{-7}$ & 10 & $3.00-5.50$ & Abbaspour et al 2001 \\
\hline $\begin{array}{l}\text { 2,3,8,9-tetraphenyl-1,4,7,10- } \\
\text { tetraazacyclododeca-1,3,7,9- } \\
\text { tetraene (TTCT) }\end{array}$ & 19.50 & $1.0 \times 10^{-1}-1.0 \times 10^{-6}$ & $7.0 \times 10^{-7}$ & 15 & $3.00-5.50$ & Ganjali et al., 2003 \\
\hline Tri-o-thymodite & 20.00 & $1.0 \times 10^{-1}-4.0 \times 10^{-6}$ & $2.0 \times 10^{-7}$ & 15 & $2.80-5.10$ & Gupta et al., 2006 \\
\hline $\begin{array}{l}\text { N-(1-thien-2-ylethylidene) } \\
\text { benzene-1,2-diamine (SNS) }\end{array}$ & 19.90 & $1.0 \times 10^{-1}-1.0 \times 10^{-6}$ & $7.0 \times 10^{-7}$ & $<12$ & $3.00-6.60$ & Ganjali et al 2006 \\
\hline $\begin{array}{l}\text { The Schiff base macrocycle } \\
\left(\mathrm{H}_{3} \mathrm{~L}\right)\end{array}$ & 20.00 & $1.0 \times 10^{-5}-1.0 \times 10^{-1}$ & $2.0 \times 10^{-5}$ & $<15$ & $2.50-3.50$ & Fekri et al., 2011 \\
\hline $\begin{array}{l}\text { Bis-(4-N-amino-5-mercapto- } \\
\text { 1,2,4-triazol-3-yl)alkane } \\
\text { (BAMTA) }\end{array}$ & 19.80 & $1.0 \times 10^{-5}-1.0 \times 10^{-1}$ & $3.0 \times 10^{-5}$ & $<10$ & $3.40-5.20$ & Kumar et al., 2013 \\
\hline $\begin{array}{l}\mathrm{N} \text { - [4-(dimetilamino) } \\
\text { benziliden] baz iyonlarının 6- } \\
\text { nitro-1,3-benzotiazol-2-amine }\end{array}$ & 19.90 & $1.0 \times 10^{-1}-1.0 \times 10^{-6}$ & $2.8 \times 10^{-7}$ & 9 & $2.00-7.00$ & Awad et al., 2014 \\
\hline Zeolite & 19.88 & $1.0 \times 10^{-7}-1.0 \times 10^{-2}$ & $6.3 \times 10^{-7}$ & 10 & $3.00-10.00$ & Heidari et al., 2016 \\
\hline In this study, item A2 & 27.12 & $1.3 \times 10^{-7}-1.0 \times 10^{-1}$ & $6.3 \times 10^{-8}$ & $\leq 10$ & $3.50-5.00$ & This work \\
\hline
\end{tabular}




\section{Conclusion}

In the current study, for the first time, a chromium (III) selective all-solid-state potentiometric sensor based on Schiff base containing acryloyl moiety as ionophore was developed. The membrane optimization studies pointed out that the appropriate ionophore among the studied ones is (E)-4-((4-chlorophenylimino) methyl) phenyl acrylate. The potentiometric performance characteristics of the proposed sensor were comparable with the other $\mathrm{Cr}$ (III) selective potentiometric sensors available in the literature. The current sensor was successfully applied for the determinations of $\mathrm{Cr}$ (III) contents in some real samples such as coffee, turmeric and drinking water. The obtained potentiometric results were found to be in accordance with the results obtained by ICP-MS. The present chromium (III)-selective potentiometric PVC membrane sensor is quite cost-effective, economical, easy to prepare, has a fast response time, and has a long life-time. With this respect, it can be an alternative device for easy, fast, lowcost, accurate and reliable $\mathrm{Cr}$ (III) determination in future applications.

\section{References}

Abbaspour, A., Izadyar, A., (2001). Chromium (III) ion-selective electrode based on 4dimethylaminoazobenzene, Talanta, 53: 1009-1013.

Altunay, N., Yıldırım, E., \& Gürkan, R. (2018). Extraction and preconcentration of trace Al and $\mathrm{Cr}$ from vegetable samples by vortex-assisted ionic liquid-based dispersive liquid-liquid microextraction prior to atomic absorption spectrometric determination, Food chemistry, 245, 586-594.

Awad, A.T., Amr L.S., Gehad, G.M., Tahani, M.B., (2014). Determination of Cr (III) ions in Different Water Samples Using Chromium (III)-sensor based on N-[4-(dimethylamino) benzylidene]-6-nitro-1,3-benzothiazol-2-amine, Int. J. Electrochem. Sci., 9: 4932-4943.

Buck, R. P., \& Lindner, E. (1994). Recommendations for nomenclature of ion-selective electrodes (IUPAC Recommendations 1994), Pure and Applied Chemistry, 66(12), 25272536.

Divrikli, U., Soylak, M., \& Elci, L. (2008). Determination of total chromium by flame atomic absorption spectrometry after coprecipitation by cerium (IV) hydroxide, Environmental monitoring and assessment, 138(1), 167-172.

Elavarasi, M., Alex, S. A., Chandrasekaran, N., \& Mukherjee, A. (2014). Simple fluorescencebased detection of $\mathrm{Cr}$ (III) and $\mathrm{Cr}$ (VI) using unmodified gold nanoparticles, Analytical Methods, 6(24), 9554-9560.

Fekri, M., Khanmohammadi, H., Darvishpour, M., (2011). An electrochemical Cr (III)Selective Sensor-Based on a Newly Synthesized Ligand and Optimization of Electrode With a Nano Particle, International Journal of electrochemical science, 1679-1685.

Gadzekpo, V.P.Y., Christian, G.D., (1984). Determination of selectivity coefficients of ionselective electrodes by a matched potential method, Analytica Chimica Acta, 164: 279-282. 
Ganjali, M.R., Mizani, F., Salavati-Niasari, M., and Javanbakht, M., (2003). Novel Potentiometric Membrane Sensor for the Determination of Trace Amounts of Chromium (III) Ions, Analytical Sciences, 19:235-238.

Ganjali, M.R., Norouzi, P., Faridbod, F., Ghorbani, M., Adib, M., (2006). Highly selective and sensitive chromium (III) membrane sensors based on a new tridentate Schiff's base, Analytica Chimica Acta, 569: 35-41.

Gholivand, M., Sharifpour, F., (2003). Chromium (III) ion-selective electrode based on glyoxal bis(2-hydroxyanil), Talanta,707-713.

Gupta, V.K., Jain, A.K., Kumar, P., Agarwal, S., Maheshwari, G., (2006). Chromium (III)selective sensor based on tri-o-thymotide in PVC matrix, Sensors and Actuators B, 113: 182186.

Hamilton, E. M., Young, S. D., Bailey, E. H., \& Watts, M. J. (2018). Chromium speciation in foodstuffs: A review, Food chemistry, 250, 105-112.

Heidari, Z., Masrournia, M., \& Khoshnood, R. S. (2016). Fabrication a composite electrode based on MWCNT/Zeolite for potentiometric determination of $\mathrm{Cr}^{3+}$, Oriental Journal of Chemistry, 32(1), 627.

Isildak, I., Yolcu, M., Isildak, O., Demirel, N., Topal, G., \& Hosgoren, H. (2004). All-solidstate PVC membrane Ag+-selective electrodes based on diaza-18-crown-6 compounds, Microchimica Acta, 144(1), 177-181.

Kaur, V., \& Malik, A. K. (2009). Speciation of chromium metal ions by RP-HPLC, Journal of chromatographic science, 47(3), 238-242.

Khound, N. J., Phukon, P., \& Bhattacharyya, K. G. (2019). Toxic Trace Metals in the Surface Water Sources of Jia-Bharali river basin, North Brahmaputra Plain, India-A Hydrochemical Elucidation, Water Resources, 46(1), 117-127.

Kimbrough, D. E., Cohen, Y., Winer, A. M., Creelman, L., \& Mabuni, C. (1999). A critical assessment of chromium in the environment, Critical reviews in environmental science and technology, 29(1), 1-46.

Kumar, K. G., \& Muthuselvi, R. (2006). Spectrophotometric determination of chromium (III) with 2-hydroxybenzaldiminoglycine, Journal of Analytical Chemistry, 61(1), 28-31.

Kumar, P., Sharma, H. K., \& Shalaan, K. G. (2013). Development of chromium (III) selective potentiometric sensor by using synthesized triazole derivative as an ionophore, Journal of Chemistry, 2013.

McIver, D. J., Grizales, A. M., Brownstein, J. S., \& Goldfine, A. B. (2015). Risk of type 2 diabetes is lower in US adults taking chromium-containing supplements, The Journal of nutrition, 145(12), 2675-2682.

Michalski, R. (2005). Trace level determination of $\mathrm{Cr}$ (III)/Cr (VI) in water samples using ion chromatography with UV detection, Journal of liquid chromatography \& related technologies, 28(18), 2849-2862. 
National Research Council (1989). Recommended dietary allowances, 10th ed., National Academy Press, Washington, DC, USA.

Pettine, M., Campanella, L., Millero, F.J., (2002). Reduction of hexavalent chromium by $\mathrm{H}_{2} \mathrm{O}_{2}$ in acidic solutions, Environmental Science and Technology, 36: 901.

Sharma, R.K., and Goel, A., (2005). Development of a Cr(III)-specific potentiometric sensor using Aurin tricarboxylic acid modified silica, Analytica Chimica Acta, 534: 137-142.

S1lku, P., Özkınalı, S., Öztürk, Z., Asan, A., \& Köse, D. A. (2016). Synthesis of novel Schiff Bases containing acryloyl moiety and the investigation of spectroscopic and electrochemical properties, Journal of Molecular Structure, 1116, 72-83.

Sun, Z., \& Liang, P. (2008). Determination of Cr (III) and total chromium in water samples by cloud point extraction and flame atomic absorption spectrometry, Microchimica Acta, 162(1-2), 121-125.

Wilson, P. B. (2019). Population-representative analysis of dietary supplementation among Americans with diabetes mellitus, Journal of diabetes, 11(2), 115-121.

Zamani, H., Ghadier, R., Ganjali, M.R., (2006). Highly selective and sensitive chromium (III) membrane sensors based on 4-amino-3-hydrazino-6-methyl-1,2,4-triazin-5-one as a new neutral ionophore, Sensors and Actuators B, 119: 41-46.

Zhao, Y., \& Han, G. (1994). Rapid spectrophotometric determination of chromium (III), Talanta, 41(8), 1247-125. 